\title{
Perception of Character Education: The Case of Lebanese School Leaders
}

\author{
Najah A. R. Ghamrawi1 ${ }^{*}$, Norma Ghamrawi1, Tarek Shal² \\ ${ }^{1}$ Faculty of Education, Lebanese University, Beirut, Lebanon \\ ${ }^{2}$ Ecole Doctorale, Lebanese University, Beirut, Lebanon \\ Email: *dr.najahghamrawi@gmail.com
}

Received 27 October 2015; accepted 22 November 2015; published 25 November 2015

Copyright (C) 2015 by authors and Scientific Research Publishing Inc.

This work is licensed under the Creative Commons Attribution International License (CC BY). http://creativecommons.org/licenses/by/4.0/

(c) (i) Open Access

\section{Abstract}

This study explored the perception of Lebanese public school leaders pertaining to character education, and their expected role within its development and effective implementation. The sample included 153 randomly selected public school principals from all the Lebanese districts (Mouhafazat). The purpose is to provide a general overview of their understanding, expectations, their knowledge of character education prescribed in the Lebanese curriculum goals, and their opinion as to the principal's role in addressing character development. The study was quantitative in nature and utilized a survey instrument that consisted of 39 items classified into 12 domains of character. The first domain targeted the knowledge of school principals pertaining to the character development goals within the Lebanese curriculum, besides their perception of school's educational mission. The other eleven domains were developed based on "The Eleven Principles of Effective Character Education" constructed by the character education partnership organization (CEP, 2014). SPSS 18.0 for windows was employed to calculate the mean and the standard deviation of responses in order to determine the perceptions of the Lebanese public school leaders related to character education. Findings suggested that Lebanese public school principals were generally not fully aware of the character goals outlined in the Lebanese curriculum and the school's educational mission concerning building students' character. Their perception on effective character education unmatched a wide scope of the eleven principles of character education. The study recommends a reform of character education in the Lebanese public schools involving the school principals as leaders of change.

\section{Keywords}

Character Education, School Leadership, School Improvement, Education Reform, School Effectiveness, Character Education Programs

\footnotetext{
"Corresponding author.
} 


\section{Introduction}

Aristotle once questioned whether education is more concerned with intellectual or moral virtue (McKeon, 1941). Moral virtue is simply an inclusive component of a current term known as "character education". Character education is a contemporary old domain that encompasses various terms of values education, moral education, civic education, social-emotional learning, citizenship education, and positive youth development (CEP, 2014). It is not only a central obligation of families, but is rather effectively developed through schooling (CEP, 2014). Berkowitz (2012) stated that "no society can survive if it does not deliberately foster the development of character in each subsequent generation of youth. And this socialization must be done by various sectors of society: family, community, media, schools and so on” (p. 1).

There are views that consider character development to be an exclusive role of parents (Wynne \& Ryan, 1997). As such, schools do not bear any responsibility in development students' overall personality and character. Contrary to this, other views attribute an important role of schools in building student character, believing that families today are challenged with various increased pressures that negatively affect the proper home support for children who miss out on some valuable life skills (Tuff, 2009). "If teaching is not occurring at home, school is the natural place, as this is where children spend [at least] 5.5 hours for 182 days a year” (Tuff, 2009: p. 1).

Research has shown that many schools with successful character education programs have experienced fewer disciplinary referrals for misbehavior, improved school attendance, fewer student drop-outs, and higher performance scores on standardized achievement tests (Wynne \& Ryan, 1997). Effective character education programs require the collaboration of all the school community that includes the principal, administrators, teachers, parents, academic staff and non-academic staff (CEP, 2014). Berkowitz (2012) stated that "a pro-active, comprehensive, collaborative and scientific approach will only make the character education initiative likely to be more effective" (p. 7).

The character education partnership organization in the United States of America (CEP, 2014) has identified a set of principles for an effective character education program. These include: 1) foundation of good character; 2) comprehensive character definitions; 3) character development approaches; 4) caring school community; 5) moral action opportunities; 6) meaningful academic curriculum; 7) students' self-motivation; 8) ethical learning community school staff; 9) shared leadership; 10) engaged families and communities; and 11) assessment based school culture (CEP, 2014).

However, the above principles would flourish and thus yield the desired outcomes only when a key condition is satisfied. In fact, research has acknowledged the bold role played by the school principals as being a determining factor for success or failure of character education; who are supposed to lead by modeling (Berkowitz, 2012). In this vein, CHARACTERplus (2007), an organization in USA that has developed a framework for comprehensive character education, reports that leadership commitment and involvement are the strongest differentiating factor between schools that implement effectively and those that do not.

While all what has been mentioned pertains to international and particularly American literature, a few studies focused on character education in the Arab world; yet there existed no Lebanese studies that particularly targeted character education in relation to leadership. Moreover, much of the available literature examined character from its narrow traditional ethical perspective rather than considering character as a comprehensive program for schools.

It is worth mentioning that "Building Character" has been identified as one of the major goals of the Lebanese curriculum (CRDP, 1997). However, there exist no comprehensive programs of character in any of the Lebanese public schools. As such, it is beneficial to explore character education from the perspective of the Lebanese public school principals. If research suggests that school principals play the key role in effective character development of students, then it is justifiable to explore whether Lebanese public school principals are serving as effective motivators for developing the character of students enrolled in Lebanese public schools.

Thus, the purpose of this study was to investigate the perception of Lebanese public school leaders pertaining to character education, and their expected role within its development and effective implementation.

\section{Objectives of the Research}

Character education is one of the Lebanese curricular goals; however no research has been conducted in order to investigate whether it is practically implemented or to explore the beliefs and understandings held by school principals. It is important to investigate the degree character education is translated in practice at the level of 
schools, so that it wouldn't remain a theory dictated by the Lebanese curriculum. It is justifiable that the study focuses particularly on the school leaders of the Lebanese public schools, as research has suggested that school leadership is one of the major standards for effective character development (Berkowitz, 2012; CEP, 2014).

Thus the purpose of this study was to explore the perception of Lebanese public school leaders pertaining to character education, and their expected role within its development and effective implementation. The study attempted to answer the following research questions:

1) How do Lebanese public school leaders value the importance of character education?

2) To what extent do the Lebanese public school leaders' perspectives coincide with the principles of effective character education?

The terms school principals and leaders are used interchangeably through the text as it is expected for school principals to act out as school leaders for the purpose of developing and nurturing character education programs (Ghamrawi, 2011).

While character is highlighted in the Lebanese curricular goals, this study investigated the extent to which character is practically implemented in the Lebanese schools. The study focused on the Lebanese public school leaders' perspectives of character education who are the major effectors for any school reform including character implementation and development (Ofsted, 2000; cited in Ghamrawi, 2011).

\section{Review of Literature}

\subsection{Definition of Character Education}

Character education is as old as education itself (Lickona, 1993). Character can be defined as a complex set of psychological characteristics, formed in part by growth in cognition that enables a person to act as a moral agent (Berkowitz \& Bier, 2004, 2005). Character is a socio-moral competency that incorporates moral action, moral values, moral personality, moral emotions, moral reasoning, moral identity, and foundational characteristics (Bajovic, 2009). Character also includes thinking, feeling, and behavior; and character strengths should be accepted as a family of positive traits reflected in those thoughts, feelings, and behaviors (Lickona, 1991; Park, 2004). Hunter (2000) defines character as the amalgamation of three elements: moral discipline, moral attachment, and moral autonomy. Good character consists of knowing the good, desiring the good, and doing the good (Lickona, 1991).

\subsection{The Return of Character Education}

Berkowitz (2012) has considered the term "character education” as simply a current term for a millennia-old issue. Down through history, education has had two great goals: to help people become smart and to help them become good (Lickona, 1993). Character education has flowed for centuries in the Western world and elsewhere (Berkowitz, 2012). The duality of purpose for education, for example, made its way into the charters of most American colleges founded prior to the late nineteenth century (Yanikoski, 2004). The Bible was the public school's sourcebook for both moral and religious instruction (Lickona, 1993).

Character education has ebbed for centuries in the Arab world and was linked to religious and moral virtues. There is even an old Arab Lebanese expression that used to be articulated by parents addressing teachers of their children: "The flesh for you and the skeleton for us". Their expression authorizes teachers for morally educating and disciplining their kids. Apparently, the statement might appear violent, yet it is an accurate analogy that reflects the cons and pros of parents' vision of character development. Negatively, it entails that "we as parents are not going to discipline our kid and please teachers do it all on our behalf". Positively, it implicitly states that "we trust you as a teacher and we respect you as a professional who is able to bring about a well-rounded person out of our child".

Lickona (1993) accurately summarized the decline and return back of character education in the American schools. He described how in the 20th century, supporters of character education began to crumble under the blows of several powerful forces of positivism which relativized and privatized morality. Morality became a matter of personal "value judgment," not a subject for public debate and transmission through the schools. However, beginning of nineties and due to societal crisis, character education made a comeback in American schools due to increased numbers of people who believed that society is in deep moral trouble and thus schools can no more play the role of "ethical bystanders". Lickona mentioned three main causes that urgently call back 
for character education: the decline of the family, troubling trends in the youth character, and the recovery of objectively shared ethical values.

A growing body of research points to the need for character education in schools, as evidenced by rising rates of juvenile crime (Britzman, 2005) and increased reports of bullying in schools (National Center for Education Statistics, 2009). A survey on school crime and safety, in the United States for the2007-2008 academic year, National Center for Education Statistics (2009) reports that bullying occurs daily or at least once a week in $20.5 \%$ of all reporting primary schools and $43.5 \%$ of all reporting middle schools. Feder (2007) emphasizes that bullying was considered a contributing factor in recent school shooting incidents and should be viewed as a serious public health problem confronting society.

As to other countries, a recent British survey of more than 1000 teachers, performed by the National Union of Teachers (NUT), has found that more than half of teachers could quit profession within two years, and one of the major reasons highlighted by more than two-thirds of teachers (67\%) was low morale of students that has declined in the past five years (Cassidy, 2015).

In Lebanon, the Center for Educational Research and Development (CERD, 1997) has highlighted "building character" as one of the main general goals for the new Lebanese curricula:

"It must be taken into account in the character building of an individual; the ability to self-realize, the sense of responsibility and the commitment to citizenship through the following fields: the mental cognitive field (knowledge and skills), the emotional affective field (attitudes and values), and the psychomotor field (behavior). These abilities are enhanced through cultural, social, artistic and sports activities that match the individual's potentials and his desires. Also, they can be reinforced by integrating them with civil education and suitable learning subjects" (CERD, 1997).

Thus, cognitive development is not the sole purpose of schooling; character development is equally important (DeRoche \& Williams, 2001).

\subsection{Effective Character Education}

According to the Character Education Partnership (CEP, 2009), 18 states in the US currently mandate character education programs, an additional 18 states encourage character education, and 7 states support character education without formal legislation. Educators have successfully used character education to transform their schools, improve school culture, increase achievement for all learners, develop global citizens, restore civility, prevent anti-social and unhealthy behaviors, and improve job satisfaction and retention among teachers (CEP, 2014).

As to the Lebanese context, few Anglo-phone private schools, have initiated character education programs several years ago. Meanwhile, the Lebanese public schools do not yet have any plan for adopting character education programs, despite the existence of international research body that emphasizes their positive impacts on the learning process.

What Works in Character Education (2005) examined 69 research studies addressing 33 character education programs. Findings underscored the fact that character education impacts a wide range of student outcomes; one of which is academic achievement. Similar findings were arrived at by studies conducted by The U.S. Department of Education (n.d.) and The Collaborative for Academic, Social, and Emotional Learning's Safe and Sound (2013).

Berkowitz (2012) describes effective character education as a "rocket science”, impacting school educational system at both the micro and macro levels. Based on the practices of effective schools, the Eleven Principles of Effective Character Education form the cornerstone of Character.org's philosophy on how best to develop and implement high-quality character education programs. As broad principles that define excellence in character education, the eleven Principles serve as guideposts that schools and others responsible for youth character development can use to plan and evaluate their programs. The eleven principles include: 1) foundation of good character; 2) comprehensive character definitions; 3) character development approaches; 4) caring school community; 5) moral action opportunities; 6) meaningful academic curriculum; 7) students' self-motivation; 8) ethical learning community school staff; 9) shared leadership; 10) engaged families and communities; and 11) assessment based school culture (CEP, 2014).

\subsection{Effective Character Education and Leadership}

Effective character education includes all stakeholders in a school community and must permeate school climate 
and curriculum (CEP, 2014). Stakeholders include principals, teachers, academic and even non-academic staff. Quality character education creates an integrated culture of character that supports and challenges students and adults to strive for excellence (CEP, 2014).

A growing body of evidence has focused attention on the importance of school leadership in character education, and in school change and reform in general. School leaders truly need to value character education, understand deeply what it entails, and have the competency to be character education instructional leaders (Berkowitz, 2012).

Leaders have roles and responsibilities if they were to administer and guide a comprehensive character education program in a school (DeRoche, 2000). Huffman (1994) clearly pointed out, character education in schools and school districts needs a strong leader, one who assumes responsibility for keeping the program on the front burner. In the same vein, DeRoche (2000) confirmed that character programs fade if there is no one in charge of the program. Helisted twelve roles and responsibilities for leaders of character education which includes leaders as: visionary, missionary, consensus builders, knowledge source, standard bearer, architects, role models, risk takers, communicators, collaborators, resource providers, and evaluators.

School principals remain the central sources of leader ship (The Wallace Foundation, 2013). The Wallace Foundation has supported efforts to improve leadership in public schools and funded projects in 28 states and numerous school districts within them, and has issued more than 70 research reports and other publications covering school leadership, on topics ranging from how principals are trained to how they are evaluated on the job. Through all this work, The Wallace Foundation (2013) highlighted a great deal about the nature of the school principal's role, what makes for an effective principal and how to tie principal effectiveness to improved student achievement. In short, The Wallace Foundation (2013) concluded that school principals are leaders who perform five key practices well: 1) shaping a vision of academic success for all students; 2) creating a climate hospitable to education; 3) cultivating leadership in others; 4) improving instruction; and 5) managing people, data and processes to foster school improvement.

Based on the aforementioned, any success for character education in the Lebanese public schools would definitely require the support of school leadership. In fact, leadership has been identified to be at the heart of the success of any educational reform (Ofsted, 2000; cited in Ghamrawi, 2011).

\section{Methodology}

\subsection{The Sample}

The invitation to participate in this study was administered to all Lebanese public school principals who were involved in a leadership development program administered by the Faculty of Education of the Lebanese University. Principals came from the six Lebanese districts "Mouhafazat": Beirut (the capital), North Lebanon, South Lebanon, Mount Lebanon, Nabatieh and Bekaa. 280 school principals were handled a copy of the survey instrument with a cover letter specifying the purpose of the study. They were informed that the data will be utilized with anonymity and confidentiality. Out of the 280 surveys, only154were returned. One of the returned survey was cancelled as it was not fully completed. Thus the sample was comprised of $\mathrm{N}=153$ public school principals.

\subsection{The Research Instruments}

The participants completed a survey on "the Perception of Character Education: The Case of Lebanese Public School Leaders" which is a modified and customized version of "The Eleven Principles of Effective Character Education" (CEP, 2010) (see Appendix). As stated earlier, the Character Education Partnership organization (CEP) has originally developed eleven quality principles to assess effective character education in the schools of the United States of America that mandate character education. Each of the eleven principles or domains consists of several elements. The researcher added a twelfth domain that targets the public school leaders' perspectives on the general mission of education in schools which is an indispensible entry step to character education in the entire Lebanese education system.

As such, the survey assesses twelve character-related domains: 1) concept of school education, 2) foundation of good character, 3) comprehensive character definitions, 4) character development approaches, 5) caring school community, 6) moral action opportunities, 7) meaningful academic curriculum, 8) students' self-motivation, 9) ethical learning community school staff, 10) shared leadership, 11) engaged families and communities, 
and 12) assessment based school culture.

The instrument consisted of 4 point Likert scale statements corresponding to four performance areas which are: "Strongly Disagree”, "Disagree”, "Agree” and "Strongly Agree”. A score of 1 indicates the public school leader strongly disagrees on that element; a score of 2 indicates that the public school leader disagrees on that element; a score of 3 entails that the public school leader agrees on that element; and a score of 4 indicates that the public school leader strongly agrees on that element. Additionally, public school leaders also completed a section on demographic information within the survey requesting them to specify their gender, age, and years of experience.

The researcher customized the tool and piloted it with a sample of 22 school principals (both public and private) who were attending a workshop organized by the researcher. Many words were amended after the conduction of the pilot study and hence the instrument was ready for administration with the research sample.

\subsection{Methods of Data Analysis}

Data was analyzed using SPSS 18.0 for windows. Descriptive statistics were used to describe and summarize the properties of the mass of data collected from the respondents. Means scores, standard deviations and percentages were calculated per each item of the survey instrument.

\section{Results}

\subsection{Demographic Data}

The sample was $45.1 \%$ males and $54.9 \%$ females. The majority (52.9\%) of public school leaders' age range was 46 and above. The novice public school leaders were no more than $7.8 \%$ while the majority (56.2\%) of public school leaders had an experience of 20 and above in administration. Bekaa and North Lebanon were the two major Lebanese districts (53.4\%) of the participants. The demographic characteristics of participants are presented in Table 1.

Table 1. Demographic characteristics of participants.

\begin{tabular}{ccc}
\hline Gender & $\%$ \\
Male & 45.1 \\
Female & 54.9 \\
Age (years) & \\
Less than 25 & 0 \\
$26-35$ & 16.3 \\
$36-45$ & 30.7 \\
46 and above & 52.9 \\
Experience (years) & \\
Less than 4 & 0 \\
5 - 9 & 7.8 \\
$10-14$ & 9.1 \\
$15-19$ & 26.7 \\
20 and above & 56.2 \\
Governorate & \\
Beirut & 7.8 \\
Bekaa & 26.7 \\
South Lebanon & 16.3 \\
Mount Lebanon & 13.0 \\
North Lebanon & 26.7 \\
Nabatieh & 9.1 \\
\hline
\end{tabular}




\subsection{Research Question 1}

How do Lebanese public school leaders value the importance of character education?

Data derived from the first domain of the survey was used to respond to the first research question. The scores obtained for the five items of the "Concept of School Education" are presented in Table 2. In general, the highest percentages recorded showed that the public school leaders agreed and strongly agreed (85.8\%) on prioritizing the academic achievements on character development upon describing their perspectives on the role of school education. Unexpectedly, and as item 1.4 indicates, the majority of public school leaders (79\%) were not aware that character development is a main general goal of the Lebanese curricula.

\subsection{Research Question 2}

To which extent do the Lebanese public school leaders' perspectives meet the principals of effective character education?

Data derived from the second to twelfth domains of the survey was used to respond to the second research question. The scores obtained for the eleven principles of effective character education are presented in Tables 3-13.

Table 4, Table 6 and Table 7 indicate that the public school leaders' perspectives "agree" to "strongly agree" on three principles of effective character education. The highest scores of agreement were recorded for the third domain (64.2\%), fifth domain (57.6\%), and sixth domain (58.5\%). The majority of public school leaders values:

Table 2. First domain scores obtained for Lebanese public school leaders via research survey.

\begin{tabular}{|c|c|c|c|c|c|c|c|c|}
\hline Item & Domain (1): Concept of school education & & $\begin{array}{l}\text { Strongly } \\
\text { disagree }\end{array}$ & Disagree & Agree & $\begin{array}{l}\text { Strongly } \\
\text { agree }\end{array}$ & $\begin{array}{l}\text { Mean } \\
\text { scores }\end{array}$ & SD \\
\hline \multirow{2}{*}{1.1.} & \multirow{2}{*}{ To educate students is to develop their cognitive abilities. } & $f$. & 6 & 11 & 72 & 64 & 3.27 & \multirow{2}{*}{.76} \\
\hline & & $\%$ & 3.8 & 7.0 & 45.9 & 40.8 & 81.7 & \\
\hline \multirow{2}{*}{1.2.} & \multirow{2}{*}{$\begin{array}{l}\text { Schools are responsible of academic achievement } \\
\text { and character development is its secondary task. }\end{array}$} & $f$. & 9 & 21 & 83 & 40 & 3.01 & \multirow{2}{*}{.79} \\
\hline & & $\%$ & 5.7 & 13.4 & 52.9 & 25.5 & 75.2 & \\
\hline \multirow{2}{*}{1.3.} & \multirow{2}{*}{$\begin{array}{l}\text { Character development is a priority task of } \\
\text { parents and caregivers while academic } \\
\text { development is a priority task of schools. }\end{array}$} & $f$. & 0 & 9 & 50 & 94 & 3.56 & \multirow{2}{*}{.60} \\
\hline & & $\%$ & $\mathbf{0}$ & 5.7 & 31.8 & 59.9 & 89 & \\
\hline \multirow{2}{*}{1.4 . } & \multirow{2}{*}{$\begin{array}{l}\text { Schools target mainly academic achievement } \\
\text { since the general goals of the Lebanese curricula } \\
\text { only target the cognitive development of students. }\end{array}$} & $f$. & 13 & 16 & 57 & 67 & 3.16 & \multirow{2}{*}{.92} \\
\hline & & $\%$ & 8.3 & 10.2 & 36.3 & 42.7 & 79 & \\
\hline \multirow{3}{*}{1.5.} & \multirow{3}{*}{$\begin{array}{l}\text { Teachers are primarily responsible of students' } \\
\text { academic achievement and secondarily responsible } \\
\text { of students’ character development. }\end{array}$} & $f$. & 0 & 10 & 11 & 132 & 3.8 & \multirow{2}{*}{.54} \\
\hline & & $\%$ & 0 & 6.5 & 7.2 & 86.3 & 95 & \\
\hline & & $A v$. & 3.5 & 8.5 & 34.8 & 51 & $84 \%$ & .72 \\
\hline
\end{tabular}

Table 3. Second domain scores obtained for Lebanese public school leaders via research survey.

\begin{tabular}{|c|c|c|c|c|c|c|c|c|}
\hline Item & $\begin{array}{l}\text { Domain (2): The school community promotes core e } \\
\text { and performance values as the foundation of good ch }\end{array}$ & & $\begin{array}{l}\text { Strongly } \\
\text { disagree }\end{array}$ & Disagree & Agree & $\begin{array}{l}\text { Strongly } \\
\text { agree }\end{array}$ & $\begin{array}{l}\text { Mean } \\
\text { scores }\end{array}$ & SD \\
\hline \multirow{2}{*}{2.1.} & \multirow{2}{*}{$\begin{array}{l}\text { Stakeholders in the school community select } \\
\text { or assent to a set of core values. }\end{array}$} & $f$. & 12 & 62 & 69 & 10 & 2.50 & \multirow{2}{*}{.73} \\
\hline & & $\%$ & 7.6 & 39.5 & 43.9 & 6.4 & 62.5 & \\
\hline \multirow{2}{*}{2.2} & \multirow{2}{*}{$\begin{array}{l}\text { Core ethical and performance values actively } \\
\text { guide every aspect of life in the school. }\end{array}$} & $f$. & 12 & 59 & 65 & 17 & 2.57 & \multirow{2}{*}{.79} \\
\hline & & $\%$ & 7.6 & 37.6 & 41.4 & 10.8 & 64.2 & \\
\hline \multirow{3}{*}{2.3.} & \multirow{3}{*}{$\begin{array}{l}\text { The school community articulates its character-related } \\
\text { goals and expectations through visible statements } \\
\text { of its core ethical and performance values. }\end{array}$} & $f$. & 21 & 82 & 46 & 4 & 2.22 & \multirow{2}{*}{.70} \\
\hline & & $\%$ & 13.4 & 52.2 & 29.3 & 2.5 & 55.5 & \\
\hline & & $A v$. & 9.5 & 43.1 & 38.2 & 8.7 & 60.7 & .74 \\
\hline
\end{tabular}


Table 4. Third domain scores obtained for Lebanese public school leaders via research survey.

\begin{tabular}{|c|c|c|c|c|c|c|c|c|}
\hline Item & $\begin{array}{l}\text { Domain (3): The school defines "character" } \\
\text { comprehensively to include thinking, feeling, and doing. }\end{array}$ & & $\begin{array}{l}\text { Strongly } \\
\text { disagree }\end{array}$ & Disagree & Agree & $\begin{array}{l}\text { Strongly } \\
\text { agree }\end{array}$ & $\begin{array}{l}\text { Mean } \\
\text { scores }\end{array}$ & SD \\
\hline \multirow{2}{*}{ 3.1. } & \multirow{2}{*}{$\begin{array}{l}\text { The school helps students acquire a developmentally } \\
\text { appropriate understanding of what the core values mean in } \\
\text { everyday behavior and grasp the reasons why some behaviors } \\
\text { represent good character and their opposites do not. }\end{array}$} & $f$. & 3 & 14 & 109 & 27 & 3.05 & \multirow{2}{*}{.58} \\
\hline & & $\%$ & 1.9 & 8.9 & 69.4 & 17.2 & 76.2 & \\
\hline \multirow{2}{*}{3.2 . } & \multirow{2}{*}{$\begin{array}{l}\text { The school helps students reflect upon the core values, } \\
\text { appreciate them, desire to demonstrate them, } \\
\text { and become committed to them. }\end{array}$} & $f$. & 4 & 26 & 38 & 85 & 3.33 & \multirow{2}{*}{.85} \\
\hline & & $\%$ & 2.5 & 16.6 & 24.2 & 54.1 & 83.2 & \\
\hline \multirow{3}{*}{ 3.3. } & \multirow{3}{*}{$\begin{array}{l}\text { The school helps students practice the core values } \\
\text { so that they become habitual patterns of behavior. }\end{array}$} & $f$. & 21 & 88 & 40 & 4 & 2.18 & \multirow{2}{*}{.68} \\
\hline & & $\%$ & 13.4 & 56.1 & 25.5 & 2.5 & 54.5 & \\
\hline & & $A v$. & 5.9 & 27.2 & 39.6 & 24.6 & 71.3 & .70 \\
\hline
\end{tabular}

Table 5. Fourth domain scores obtained for Lebanese public school leaders via research survey.

\begin{tabular}{|c|c|c|c|c|c|c|c|c|}
\hline Item & $\begin{array}{l}\text { Domain (4): The school uses a comprehensive, intentio } \\
\text { and proactive approach to character development. }\end{array}$ & & $\begin{array}{l}\text { Strongly } \\
\text { disagree }\end{array}$ & Disagree & Agree & $\begin{array}{l}\text { Strongly } \\
\text { agree }\end{array}$ & $\begin{array}{l}\text { Mean } \\
\text { scores }\end{array}$ & SD \\
\hline \multirow{2}{*}{4.1.} & \multirow{2}{*}{$\begin{array}{l}\text { The school is intentional and proactive } \\
\text { in addressing character at all grade levels. }\end{array}$} & $f$. & 2 & 56 & 89 & 6 & 2.65 & \multirow{2}{*}{.57} \\
\hline & & $\%$ & 1.3 & 35.7 & 56.7 & 3.8 & 66.2 & \\
\hline \multirow{2}{*}{4.2.} & \multirow{2}{*}{$\begin{array}{l}\text { Character education is integrated into } \\
\text { academic content and instruction. }\end{array}$} & $f$. & 33 & 95 & 17 & 8 & 2.00 & \multirow{2}{*}{.73} \\
\hline & & $\%$ & 21.0 & 60.5 & 10.8 & 5.1 & 50 & \\
\hline \multirow{2}{*}{4.3.} & \multirow{2}{*}{$\begin{array}{l}\text { Character education is a priority } \\
\text { in how teachers conduct their classes. }\end{array}$} & $f$. & 22 & 47 & 23 & 61 & 2.8 & \multirow{2}{*}{.72} \\
\hline & & $\%$ & 14.0 & 29.9 & 14.6 & 38.9 & 70 & \\
\hline \multirow{3}{*}{4.4.} & \multirow{3}{*}{$\begin{array}{l}\text { Character education is infused throughout the school day } \\
\text { in classes, sports, meetings, and co-curricular activities. }\end{array}$} & $f$. & 29 & 62 & 15 & 47 & 2.5 & \multirow{2}{*}{.71} \\
\hline & & $\%$ & 18.5 & 39.5 & 9.6 & 29.9 & 62.5 & \\
\hline & & $A v$. & 13.7 & 41.4 & 22.9 & 19.4 & 62.1 & .68 \\
\hline
\end{tabular}

Table 6. Fifth domain scores obtained for Lebanese public school leaders via research survey.

\begin{tabular}{|c|c|c|c|c|c|c|c|c|}
\hline Item & Domain (5): The school creates a caring community. & & $\begin{array}{l}\text { Strongly } \\
\text { disagree }\end{array}$ & Disagree & Agree & $\begin{array}{l}\text { Strongly } \\
\text { agree }\end{array}$ & $\begin{array}{l}\text { Mean } \\
\text { scores }\end{array}$ & SD \\
\hline \multirow{2}{*}{5.1.} & \multirow{2}{*}{$\begin{array}{l}\text { The school makes it a high priority to } \\
\text { foster caring attachments between students and staff. }\end{array}$} & $f$ & 23 & 86 & 44 & 0 & 2.14 & \multirow{2}{*}{.64} \\
\hline & & $\%$ & 14.6 & 54.8 & 28.0 & $\mathbf{0}$ & 53.5 & \\
\hline \multirow{2}{*}{5.2.} & \multirow{2}{*}{$\begin{array}{l}\text { The school makes it a high priority to help students } \\
\text { form caring attachments to each other. }\end{array}$} & $f$ & 0 & 74 & 79 & 0 & 2.52 & \multirow{2}{*}{.50} \\
\hline & & $\%$ & $\mathbf{0}$ & 47.1 & 50.3 & $\mathbf{0}$ & 63 & \\
\hline \multirow{2}{*}{5.3.} & \multirow{2}{*}{$\begin{array}{l}\text { The school takes steps to prevent peer cruelty and } \\
\text { violence and deals with it effectively when it occurs. }\end{array}$} & $f$. & 0 & 0 & 132 & 21 & 3.14 & \multirow{2}{*}{.34} \\
\hline & & $\%$ & $\mathbf{0}$ & $\mathbf{0}$ & 84.1 & 13.4 & 78.5 & \\
\hline \multirow{3}{*}{5.4} & \multirow{3}{*}{$\begin{array}{l}\text { The school makes it a high priority to foster caring } \\
\text { attachments among adults within the school community. }\end{array}$} & $f$. & 1 & 66 & 85 & 1 & 2.56 & \multirow{2}{*}{.52} \\
\hline & & $\%$ & .6 & 42.0 & 54.1 & .6 & 64 & \\
\hline & & $A v$. & 3.8 & 35.9 & 54.1 & 3.5 & 64.7 & .50 \\
\hline
\end{tabular}


Table 7. Sixth domain scores obtained for Lebanese public school leaders via research survey.

\begin{tabular}{|c|c|c|c|c|c|c|c|c|}
\hline Item & $\begin{array}{l}\text { Domain (6): The school provides students } \\
\text { with opportunities for moral action. }\end{array}$ & & $\begin{array}{l}\text { Strongly } \\
\text { disagree }\end{array}$ & Disagree & Agree & $\begin{array}{l}\text { Strongly } \\
\text { agree }\end{array}$ & $\begin{array}{l}\text { Mean } \\
\text { scores }\end{array}$ & SD \\
\hline \multirow{2}{*}{ 6.1. } & \multirow{2}{*}{$\begin{array}{l}\text { The school sets clear expectations for students to engage } \\
\text { in actions that develop and demonstrate good character. }\end{array}$} & $f$. & 23 & 86 & 44 & 0 & 2.56 & \multirow{2}{*}{.52} \\
\hline & & $\%$ & 14.6 & 54.8 & 28.0 & 0 & 64 & \\
\hline \multirow{2}{*}{ 6.2. } & \multirow{2}{*}{$\begin{array}{l}\text { The school provides all students with varied opportunities for } \\
\text { engaging in positive, responsible action within the school, and } \\
\text { students engage in these opportunities and reflect on them. }\end{array}$} & $f$. & 0 & 74 & 79 & 0 & 2.14 & \multirow{2}{*}{.64 } \\
\hline & & $\%$ & $\mathbf{0}$ & 47.1 & 50.3 & 0 & 53.5 & \\
\hline \multirow{3}{*}{ 6.3. } & \multirow{3}{*}{$\begin{array}{l}\text { The school provides all students with repeated and varied } \\
\text { opportunities for making contributions to the larger community, } \\
\text { and students engage in these opportunities and reflect on them. }\end{array}$} & $f$. & 0 & 0 & 132 & 21 & 2.52 & \multirow{2}{*}{.50} \\
\hline & & $\%$ & 0 & $\mathbf{0}$ & 84.1 & 13.4 & 63 & \\
\hline & & $A v$. & 0.3 & 33.9 & 54.1 & 4.4 & 60.1 & .55 \\
\hline
\end{tabular}

Table 8. Seventh domain scores obtained for Lebanese public school leaders via research survey.

\begin{tabular}{|c|c|c|c|c|c|c|c|c|}
\hline Item & $\begin{array}{l}\text { Domain (7): The school offers a meaningful and } \\
\text { challenging academic curriculum that respects all learners, } \\
\text { develops their character, and helps them to succeed. }\end{array}$ & & $\begin{array}{l}\text { Strongly } \\
\text { disagree }\end{array}$ & Disagree & Agree & $\begin{array}{l}\text { Strongly } \\
\text { agree }\end{array}$ & $\begin{array}{l}\text { Mean } \\
\text { scores }\end{array}$ & SD \\
\hline \multirow{2}{*}{ 7.1. } & \multirow{2}{*}{$\begin{array}{l}\text { The academic curriculum provides meaningful } \\
\text { and appropriate challenges to all students. }\end{array}$} & $f$. & 36 & 95 & 13 & 9 & 1.97 & \multirow{2}{*}{.74} \\
\hline & & $\%$ & 22.9 & 60.5 & 8.3 & 5.7 & 49.2 & \\
\hline \multirow{2}{*}{7.2.} & \multirow{2}{*}{$\begin{array}{l}\text { The school staff identifies, understands, } \\
\text { and accommodates the diverse interests, } \\
\text { cultures, and learning needs of all students. }\end{array}$} & $f$. & 32 & 91 & 17 & 13 & 2.07 & \multirow[t]{2}{*}{.81} \\
\hline & & $\%$ & 20.4 & 58.0 & 10.8 & 8.3 & 51.7 & \\
\hline \multirow{3}{*}{ 7.3. } & \multirow{3}{*}{$\begin{array}{l}\text { Teachers promote the development of performance } \\
\text { character traits that support students' intellectual growth, } \\
\text { academic performance, and capacity for } \\
\text { both self-direction and teamwork. }\end{array}$} & $f$. & 0 & 95 & 24 & 34 & 2.6 & \multirow{2}{*}{.83} \\
\hline & & $\%$ & 0 & 60.5 & 15.3 & 21.7 & 65 & \\
\hline & & $A v$. & 14.4 & 59.6 & 11.4 & 11.9 & 55.3 & .79 \\
\hline
\end{tabular}

Table 9. Eighth domain scores obtained for Lebanese public school leaders via research survey.

\begin{tabular}{|c|c|c|c|c|c|c|c|c|}
\hline Item & Domain (8): The school fosters students' self-motivation. & & $\begin{array}{l}\text { Strongly } \\
\text { disagree }\end{array}$ & Disagree & Agree & $\begin{array}{l}\text { Strongly } \\
\text { agree }\end{array}$ & $\begin{array}{l}\text { Mean } \\
\text { scores }\end{array}$ & SD \\
\hline \multirow{2}{*}{8.1.} & \multirow{2}{*}{$\begin{array}{l}\text { Staff and students recognize and celebrate the natural, } \\
\text { beneficial consequences of facts of character rather than } \\
\text { rewarding students with material recognition or rewards. }\end{array}$} & $f$. & 11 & 76 & 53 & 13 & 2.44 & \multirow{2}{*}{.75} \\
\hline & & $\%$ & 7.0 & 48.4 & 33.8 & 8.3 & 61 & \\
\hline \multirow{3}{*}{8.2.} & \multirow{3}{*}{$\begin{array}{l}\text { The school's approach to student conduct uses all aspects } \\
\text { of behavior management as opportunities to foster students' } \\
\text { character development, especially their understanding } \\
\text { of and commitment to core values. }\end{array}$} & $f$. & 11 & 53 & 56 & 33 & 2.73 & \multirow{2}{*}{.88} \\
\hline & & $\%$ & 7.0 & 33.8 & 35.7 & 21.0 & 68.2 & \\
\hline & & $A v$. & 7 & 41.1 & 34.7 & 14.6 & 64.6 & .81 \\
\hline
\end{tabular}

Table 10. Ninth domain scores obtained for Lebanese public school leaders via research survey.

\begin{tabular}{|c|c|c|c|c|c|c|c|c|}
\hline Item & $\begin{array}{l}\text { Domain (9): The school staff is an ethical learning con } \\
\text { that shares responsibility for character education and } \\
\text { to the same core values that guide the students }\end{array}$ & & $\begin{array}{l}\text { Strongly } \\
\text { disagree }\end{array}$ & Disagree & Agree & $\begin{array}{c}\text { Strongly } \\
\text { agree }\end{array}$ & $\begin{array}{l}\text { Mean } \\
\text { scores }\end{array}$ & $\mathrm{SD}$ \\
\hline \multirow{2}{*}{9.1.} & $\begin{array}{l}\text { Staff members model the core values in their } \\
\text { interactions with students and each other, }\end{array}$ & $f$ & 2 & 10 & 134 & 7 & & \multirow[t]{2}{*}{.40} \\
\hline & and students and parents perceive that they do. & $\%$ & 1.3 & 6.4 & 85.4 & 4.5 & 73.7 & \\
\hline \multirow{2}{*}{9.2.} & The school includes all staff in planning, & $f$. & 3 & 143 & 3 & 4 & 2.05 & \multirow{2}{*}{.37} \\
\hline & out the school wide character education initiative. & $\%$ & 1.9 & 91.1 & 1.9 & 2.5 & 51.2 & \\
\hline \multirow{3}{*}{9.3.} & \multirow{3}{*}{$\begin{array}{l}\text { The school makes time available for staff planning } \\
\text { and reflection in regard to character education. }\end{array}$} & $f$. & 3 & 126 & 20 & 4 & 2.16 & \multirow{2}{*}{.47} \\
\hline & & $\%$ & 1.9 & 80.3 & 12.7 & 2.5 & 54 & \\
\hline & & $A v$. & 1.7 & 59.2 & 33.3 & 3.1 & 59.6 & .41 \\
\hline
\end{tabular}


Table 11. Tenth domain scores obtained for Lebanese public school leaders via research survey.

\begin{tabular}{|c|c|c|c|c|c|c|c|c|}
\hline Item & $\begin{array}{c}\text { Domain (10): The school fosters shared leadership and long } \mathrm{r} \\
\text { support of the character education initiative. }\end{array}$ & nge & $\begin{array}{l}\text { Strongly } \\
\text { disagree }\end{array}$ & Disagree & Agree & $\begin{array}{l}\text { Strongly } \\
\text { agree }\end{array}$ & $\begin{array}{l}\text { Mean } \\
\text { scores }\end{array}$ & SD \\
\hline \multirow{2}{*}{10.1 . } & \multirow{2}{*}{$\begin{array}{l}\text { The school's character education initiative has leaders, } \\
\text { including the school principal, who champion character } \\
\text { education efforts, share leadership, } \\
\text { and provide long-range support. }\end{array}$} & $f$ & 0 & 10 & 98 & 45 & 3.23 & \multirow{2}{*}{.55} \\
\hline & & $\%$ & $\mathbf{0}$ & 6.4 & 62.4 & 28.7 & 80.7 & \\
\hline \multirow[b]{2}{*}{10.2 . } & \multirow{2}{*}{$\begin{array}{l}\text { A leadership group or structure (several linked groups) } \\
\text { inclusive of staff, students, and parents guides the ongoing } \\
\text { planning and implementation of the character education } \\
\text { initiative and encourages the involvement of the } \\
\text { whole school in character-related activities. }\end{array}$} & $f$. & 47 & 82 & 15 & 9 & 1.91 & \multirow[b]{2}{*}{.79} \\
\hline & & $\%$ & 29 & 52.2 & 9.6 & 5.7 & 47.7 & \\
\hline \multirow{3}{*}{10.3.} & \multirow{3}{*}{$\begin{array}{l}\text { Students are explicitly involved in creating and maintaining } \\
\text { a sense of community and in other leadership roles } \\
\text { that contribute to the character education effort. }\end{array}$} & $f$. & 6 & 73 & 56 & 18 & 2.56 & \multirow{2}{*}{.75} \\
\hline & & $\%$ & 3.8 & 46.5 & 35.7 & 11.5 & 64 & \\
\hline & & $A v$. & 10.9 & 35 & 35.9 & 15.3 & 64.1 & .69 \\
\hline
\end{tabular}

Table 12. Eleventh domain scores obtained for Lebanese public school leaders via research survey.

\begin{tabular}{|c|c|c|c|c|c|c|c|c|}
\hline Item & $\begin{array}{l}\text { Domain (11): The school engages families and community } \\
\text { members as partners in the character-building effort. }\end{array}$ & & $\begin{array}{l}\text { Strongly } \\
\text { disagree }\end{array}$ & Disagree & Agree & $\begin{array}{l}\text { Strongly } \\
\text { agree }\end{array}$ & $\begin{array}{l}\text { Mean } \\
\text { scores }\end{array}$ & SD \\
\hline \multirow{2}{*}{11.1.} & \multirow{2}{*}{$\begin{array}{l}\text { The school engages families in the character } \\
\text { education initiative. }\end{array}$} & $f$. & 18 & 72 & 57 & 6 & 2.33 & \multirow{2}{*}{.73} \\
\hline & & $\%$ & 11.5 & 45.9 & 36.3 & 3.8 & 58.2 & \\
\hline \multirow{3}{*}{11.2 . } & \multirow{3}{*}{$\begin{array}{l}\text { The administration and faculty regularly communicate } \\
\text { with parents and guardians, providing suggestions and } \\
\text { activities that help them reinforce the core values, and they } \\
\text { survey parents, both formally and informally, on the } \\
\text { effectiveness of the school's character education efforts. }\end{array}$} & $f \cdot$ & 9 & 92 & 52 & 0 & 2.28 & \multirow{3}{*}{.56} \\
\hline & & & & & & & & \\
\hline & & $\%$ & 5.7 & 58.6 & 33.1 & $\mathbf{0}$ & 57 & \\
\hline \multirow{3}{*}{11.3.} & \multirow{3}{*}{ The school recruits the help of the wider community. } & $f$. & 11 & 21 & 115 & 6 & 2.76 & \multirow{2}{*}{.63} \\
\hline & & $\%$ & 7.0 & 13.4 & 73.2 & 3.8 & 69 & \\
\hline & & $A v$. & 13.8 & 39.3 & 47.5 & 2.5 & 61.4 & .64 \\
\hline
\end{tabular}

Table 13. Twelfth domain scores obtained for Lebanese public school leaders via research survey.

\begin{tabular}{|c|c|c|c|c|c|c|c|c|}
\hline Item & $\begin{array}{l}\text { Domain (12): The school regularly assesses its culture } \\
\text { and climate, the functioning of its staff as character educa } \\
\text { and the extent to which its students manifest good charac }\end{array}$ & & $\begin{array}{l}\text { Strongly } \\
\text { disagree }\end{array}$ & Disagree & Agree & $\begin{array}{c}\text { Strongly } \\
\text { agree }\end{array}$ & $\begin{array}{l}\text { Mean } \\
\text { scores }\end{array}$ & SD \\
\hline \multirow{2}{*}{12.1.} & The school sets goals and regularly assesses & $f$. & 111 & 11 & 18 & 13 & 1.56 & \multirow{2}{*}{.79} \\
\hline & climate, and functioning as an ethical learning community. & $\%$ & 70.7 & 7.0 & 11.5 & 8.3 & 39 & \\
\hline \multirow{2}{*}{12.2.} & Staff members reflect upon and report on their efforts & $f$. & 111 & 20 & 16 & 6 & 1.46 & \multirow{2}{*}{.63} \\
\hline & on their growth as character educators. & $\%$ & 70.7 & 12.7 & 10.2 & 3.8 & 36.5 & \\
\hline \multirow{3}{*}{ 12.3. } & The school assesses student progress in developing an & $f$. & 15 & 53 & 70 & 15 & 2.56 & \multirow{2}{*}{.80} \\
\hline & and the degree to which students act upon the core values. & $\%$ & 9.6 & 33.8 & 44.6 & 9.6 & 64 & \\
\hline & & $A v$. & 50.3 & 17.8 & 22.1 & 7.2 & 46.5 & .74 \\
\hline
\end{tabular}

the importance of comprehensively defining character to include thinking, feeling and doing, the creation of a caring school community, and the role of schools in providing opportunities for moral action.

Contrary to that, Table 3, Table 5, Table 8, Table 10 and Table 13 indicate that the public school leaders' perspectives "disagree” to "strongly disagree" on five principles of effective character education. The highest scores of disagreement were recorded for the second domain (52.6\%), fourth domain (55.1\%), seventh domain (74\%), ninth domain (60.9\%), and twelfth domain (68.1\%). The majority of public school leaders underestimates: the role of school community in promoting the foundation of good character, the school's comprehensive 
intentional proactive approach to character development, the role of schools in offering a character related academic curriculum, the shared responsibilities of all school staff members in character development, and the importance of assessment in character development.

\section{Conclusion}

This study investigated the perception of the Lebanese public school leaders for character education; an area of research that has never been addressed before in Lebanon and Arab region. Findings indicate that the Lebanese public school leaders perceive character education as a secondary mission of school education and thus prioritizes schools' role in academic achievement. Their vision towards character education goes opposite to the general goals of the Lebanese curriculum which highlights "Building Character" as one of its major targets (CRDP, 1997). This finding is inconsistent with the research studies that emphasize the school's role in developing character education as a condition for a society to survive and this socialization must be done by various sectors of society: family, community, media, and mainly schools (Berkowitz, 2012).

As for the principles of CEP that frame effective character education, the Lebanese public school leaders valued the importance of comprehensively defining character to include thinking, feeling and doing, the creation of a caring school community, and the role of schools in providing opportunities for moral action. On the contrary, they belittled the role of school community in promoting the foundation of good character, the school's comprehensive intentional proactive approach to character development, the role of schools in offering a character related academic curriculum, the shared responsibilities of all school staff members in character development, and the importance of assessment in character development. These findings widely diverge from the principals of effective character education (CEP, 2014).

Therefore, the goal of "Building Character" in the Lebanese curriculum should get realized. Then the first step would definitely require building the capacity of Lebanese school leaders to act as champions of change and as incubators who can provide full support for such notion. Principals need to recognize that schools are places for the overall development of students and not only their cognitive abilities. Any reform effort should focus on leadership, as leadership lies at the heart of the success of any educational reform (Ofsted, 2000; cited in Ghamrawi, 2011). Character Education and Character Education programs are not exceptions to this rule.

\subsection{Limitations of the Study}

Several issues constitute limitations to the current study. These include:

1) Research Instruments: The research instrument “Character Education Survey” originally developed by CEP (2014) in order to assess the quality of character programs implemented in the American schools. In this study it was adapted and customized so as to de administered to the Lebanese public school leaders. Though a pilot study was carried out in order to assure its validity and reliability; other rigorous large scale tests need to be administered to assure these concerns.

2) The Sample: Only 153 out of 1273 Lebanese public school leaders (CRDP, 2014) from all the Lebanese districts participated in this study. This constitutes approximately $12 \%$ of the Lebanese public school leaders. Such a percentage indicates that the results are not very generable; though several important lessons may be derived.

3) Another issue is that all participants were enrolled in a leadership development program administered by the Faculty of Education at the Lebanese University. Thus, findings from this sample might be leveraged by the fact that the principals were involved in such a program which enhances their leadership skills.

\subsection{Recommendations}

This study indicates that character education remains as a theoretical goal of the Lebanese education system. The Lebanese public school leaders prioritize the academic role of schools on character development despite the fact that "Building Character" is a major goal of the Lebanese curriculum. In addition, the perspectives of public school leaders unmet a wide scope of the quality principles for effective character education. However, with the limitations described above, additional research is needed to validate the findings of this study. Ideas for future research should focus on: 1) investigating the same topic qualitatively; 2) using a more representative sample of the Lebanese Public School Leader Population; 3) invite public school leaders to a character training program 
and compare their perspectives pre and post the program; and 4) examining, through a pilot study, the impact of a comprehensive character program on a public school community.

Also, this study has indicated that the perception of the Lebanese public school leaders for character education is incompatible with the literature of effective character education. If the theory of "Building Character" in the Lebanese curriculum is to be practiced in action, then the first step would definitely require the support of school leadership. Thus, policy makers at the ministry of education and higher education (MEHE) as well as program designers at the training design centers should rethink training design, considering the importance of educating school leaders on issues pertaining to character development and character education.

\section{References}

Bajovic, M., Rizzo, K., \& Engemann, J. (2009). Character Education Re-Conceptualized for Practical Implementation. Canadian Journal of Educational Administration and Policy, 92.

Berkowitz, M. W., \& Bier, M. C. (2004). Research-Based Character Education. The Annals of the American Academy of Political and Social Science, 591, 72-85.

Berkowitz, M. W., \& Bier, M. C. (2005). What Works in Character Education: A Research-Driven Guide for Education. Washington DC: Character Education Partnership. http://www.charatcterandcitizenship.org

Berkowitz, M. (2012). Understanding Effective Character Education. The Literacy and Numeracy Secretariat Capacity Building Series. http://www.edu.gov.on.ca/eng/literacynumeracy/inspire/research/Expert Perspectives.pdf

Britzman, M. (2005). Improving Our Moral Landscape via Character Education: An Opportunity for School Counselor Leadership. Professional School Counseling, 8, 293-295.

Cassidy, S. (2015). More than Half of Teachers Could Quit Profession within Two Years, Says Study. The Independent. http://www.independent.co.uk/news/education/education-news/

CEP (2009). Character Education: What States Are Doing. www.character.org

CEP (2014). A Framework for School Success: Eleven Principles of Effective Character Education. www.character.org

CRDP (1997). The Lebanese Curriculum General Goals. http://www.crdp.org/en/desc-curriculum-structure

CRDP (2014). Statistics Bulletin. http://www.crdp.org/en/desc-curriculum-structure

DeRoche, E. F. (2000). Leadership for Character Education Programs. Journal of Humanistic Counseling, Education \& Development, 39, 41-46. http://dx.doi.org/10.1002/j.2164-490X.2000.tb00092.x

DeRoche, E. F., \& Williams, M. M. (2001). Character Education: A Guide for School Administrators. Lanham, MD: Scarecrow.

Feder, L. (2007). Bullying as a Public Health Issue. International Journal of Offender Therapy and Comparative Criminology, 51, 491-494. http://dx.doi.org/10.1177/0306624X07308081

Ghamrawi, N. (2011). Trust Me. Your School Can Do Better-A Message from Teachers to Principals. Educational Management Administration and Leadership, 39, 333-348. http://dx.doi.org/10.1177/1741143210393997

Huffman, H. (1994). Developing a Character Education Program: One School District's Experience. Alexandria, VA: Association for Supervision and Curriculum Development.

Hunter, J. D. (2000). The Death of Character: Moral Education in an Age without Good or Evil. New York: Basic Books.

Lickona, T. (1991). Educating for Character. New York: Bantam.

Lickona, T. (1993). The Return of Character Education. Educational Leadership, 5, 6-11.

McKeon, R. (1941). The Basic Works of Aristotle. New York: Random House.

National Center for Education Statistics (2009). Crime, Violence, Discipline, and Safety in US Public Schools: Findings from the School Survey on Crime and Safety: 2007-2008. http://nces.ed.gov/

CHARACTERplus (2007). The CHARACTERplus Way Results Monograph. Building a Healthy School Community: Experimental Evidence That the CHARACTERplus Way Works. www.characterplus.org

The Wallace Foundation (2013). The School Principal as Leader: Guiding Schools to Better Teaching and Learning. www.wallacefou ndation.org

United States Department of Education (n.d.). What Works Clearinghouse: Character Education. http://www.whatworks.ed.gov

Yanikoski, R. (2004). Leadership Perspectives on the Role of Character Development in Higher Education. New Directions for Institutional Research, 2004, 7-23. http://dx.doi.org/10.1002/ir.106 


\section{Appendix}

Survey on the Perception of Character Education: The Case of Lebanese Public School Leaders.

Modified Version of “The Eleven Principles of Effective Character Education” (CEP, 2010).

Instructions: Please complete the following survey to reflect your opinions as accurately as possible on the role of Lebanese schools in character education. Use the scaling key below:

\begin{tabular}{|c|c|c|c|c|c|}
\hline & Domain (1): Concept of school education & 1 & 2 & 3 & 4 \\
\hline 1.1 & To educate students is to develop their cognitive abilities. & & & & \\
\hline 1.2 & Schools are responsible of academic achievement and character development is its secondary task. & & & & \\
\hline 1.3 & $\begin{array}{l}\text { Character development is a priority task of parents and caregivers } \\
\text { while academic development is a priority task of schools. }\end{array}$ & & & & \\
\hline 1.4 & $\begin{array}{l}\text { Schools target mainly academic achievement since the general goals of the } \\
\text { Lebanese curricula only target the cognitive development of students. }\end{array}$ & & & & \\
\hline \multirow[t]{2}{*}{1.5} & $\begin{array}{l}\text { Teachers are primarily responsible of students' academic achievement } \\
\text { and secondarily responsible of students’ character development. }\end{array}$ & & & & \\
\hline & $\begin{array}{c}\text { Domain (2): The school community promotes core ethical and performance values as } \\
\text { the foundation of good character. }\end{array}$ & 1 & 2 & 3 & 4 \\
\hline 2.1 & Stakeholders in the school community select or assent to a set of core values. & & & & \\
\hline 2.2 & Core ethical and performance values actively guide every aspect of life in the school. & & & & \\
\hline \multirow[t]{2}{*}{2.3} & $\begin{array}{l}\text { The school community articulates its character-related goals and expectations } \\
\text { through visible statements of its core ethical and performance values. }\end{array}$ & & & & \\
\hline & Domain (3): The school defines “character" comprehensively to include thinking, feeling, and doing. & 1 & 2 & 3 & 4 \\
\hline 3.1 & $\begin{array}{l}\text { The school helps students acquire a developmentally appropriate understanding } \\
\text { of what the core values mean in everyday behavior and grasp the reasons } \\
\text { why some behaviors represent good character and their opposites do not. }\end{array}$ & & & & \\
\hline 3.2 & $\begin{array}{l}\text { The school helps students reflect upon the core values, appreciate them, } \\
\text { desire to demonstrate them, and become committed to them. }\end{array}$ & & & & \\
\hline \multirow[t]{2}{*}{3.3} & The school helps students practice the core values so that they become habitual patterns of behavior. & & & & \\
\hline & Domain (4): The school uses a comprehensive, intentional, and proactive approach to character development. & 1 & 2 & 3 & 4 \\
\hline 4.1 & The school is intentional and proactive in addressing character at all grade levels. & & & & \\
\hline 4.2 & Character education is integrated into academic content and instruction. & & & & \\
\hline 4.3 & Character education is a priority in how teachers conduct their classes. & & & & \\
\hline \multirow[t]{2}{*}{4.4} & $\begin{array}{l}\text { Character education is infused throughout the school day in classes, } \\
\text { sports, meetings, and co-curricular activities. }\end{array}$ & & & & \\
\hline & Domain (5): The school creates a caring community. & 1 & 2 & 3 & 4 \\
\hline 5.1 & The school makes it a high priority to foster caring attachments between students and staff. & & & & \\
\hline 5.2 & The school makes it a high priority to help students form caring attachments to each other. & & & & \\
\hline 5.3 & The school takes steps to prevent peer cruelty and violence and deals with it effectively when it occurs. & & & & \\
\hline \multirow[t]{2}{*}{5.4} & The school makes it a high priority to foster caring attachments among adults within the school community. & & & & \\
\hline & Domain (6): The school provides students with opportunities for moral action. & 1 & 2 & 3 & 4 \\
\hline 6.1 & $\begin{array}{l}\text { The school sets clear expectations for students to engage in actions } \\
\text { that develop and demonstrate good character. }\end{array}$ & & & & \\
\hline 6.2 & $\begin{array}{l}\text { The school provides all students with varied opportunities for engaging in positive, responsible } \\
\text { action within the school, and students engage in these opportunities and reflect on them. }\end{array}$ & & & & \\
\hline 6.3 & $\begin{array}{l}\text { The school provides all students with repeated and varied opportunities for making contributions } \\
\text { to the larger community, and students engage in these opportunities and reflect on them. }\end{array}$ & & & & \\
\hline
\end{tabular}




\section{Continued}

Domain (7): The school offers a meaningful and challenging academic curriculum that respects all learners, develops their character, and helps them to succeed.

The academic curriculum provides meaningful and appropriate challenges to all students.

The school staff identifies, understands, and accommodates the diverse interests, cultures, and learning needs of all students.

Teachers promote the development of performance character traits that support students' intellectual growth, academic performance, and capacity for both self-direction and teamwork.

\section{Domain (8): The school fosters students' self-motivation.}

8.1

Staff and students recognize and celebrate the natural, beneficial consequences of facts of character rather than rewarding students with material recognition or rewards.

8.2

The school's approach to student conduct uses all aspects of behavior management as opportunities to foster students' character development, especially their understanding of and commitment to core values.

Domain (9): The school staff is an ethical learning community that shares responsibility for character education and adheres to the same core values that guide the students.

9.1 Staff model the core values in their interactions with students and each other, and students and parents perceive that they do. and carrying out the school wide character education initiative.

10.1 The school's character education initiative has leaders, including the school principal, who champion character education efforts, share leadership, and provide long-range support.

A leadership group or structure (several linked groups) inclusive of staff, students, and parents guides the ongoing planning and implementation of the character education initiative and encourages the involvement of the whole school in character-related activities.

10.3 Students are explicitly involved in creating and maintaining a sense of community and in other leadership roles that contribute to the character education effort.

Domain (11): The school engages families and community members as partners in the character-building effort.

The school engages families in the character education initiative.

The administration and faculty regularly communicate with parents and guardians, providing suggestions and activities that help them reinforce the core values, and they survey parents, both formally and informally, on the effectiveness of the school's character education efforts. as character educators, and the extent to which its students manifest good character.

12.1 The school sets goals and regularly assesses (both quantitatively and qualitatively) its culture, climate, and functioning as an ethical learning community.

Staff members reflect upon and report on their efforts to implement character education, as well as on their growth as character educators. good character and the degree to which students act upon the core values.

1 = Strongly disagree; 2 = Disagree; 3 = Agree; 4 = Strongly agree. Note: Your information will be kept strictly confidential . 